\title{
Metastatic Infiltrating Bladder Urothelial Carcinoma, Clear Cell Variant
}

National Cancer Institute

\section{Source}

National Cancer Institute. Metastatic Infiltrating Bladder Urothelial Carcinoma, Clear Cell

Variant. NCI Thesaurus. Code C157768.

Bladder clear cell variant urothelial carcinoma that has spread to another anatomical site. 